\title{
ORGANIC MATTER AND NITROGEN REMOVAL IN ROTARY DISK TYPE UF MEMBRANE BIOREACTOR FOR FERMENTATION WASTEWATER TREATMENT
}

\author{
Shuguang $\mathrm{LU}^{1}$, Tsuyoshi IMAI ${ }^{2}$, Masao UKITA ${ }^{3}$, Masahiko SEKINE ${ }^{4}$, \\ Masayuki FUKAGAWA ${ }^{5}$ and Hiroshi NAKANISHI ${ }^{6}$ \\ 'Member of JSCE, M. Eng., Graduate Student, Dept. of Civil Eng., Yamaguchi University \\ ( Ube, Yamaguchi 755-8611, Japan ) \\ ${ }^{2}$ Member of JSCE, Dr. Eng., Research Associate, Dept. of Civil Eng., Yamaguchi University \\ ( Ube, Yamaguchi 755-8611, Japan ) \\ ${ }^{3}$ Member of JSCE, Dr. Eng., Professor, Dept. of Civil Eng., Yamaguchi University \\ ( Ube, Yamaguchi 755-8611, Japan ) \\ ${ }^{4}$ Member of JSCE, Dr. Eng., Assistant Professor, Dept. of Civil Eng., Yamaguchi University \\ ( Ube, Yamaguchi 755-8611, Japan ) \\ ${ }^{5}$ Member of JSCE, Dr. Eng., Professor, Dept. of Chemical and Biological Eng., Ube National College of Technology \\ ( Ube, Yamaguchi 755-8555, Japan ) \\ ${ }^{6}$ Member of JSCE, Dr. Eng., Emeritus Professor, Yamaguchi University \\ ( Ube, Yamaguchi 755-8611, Japan )
}

\begin{abstract}
Various intermittent aeration modes were applied to treat fermentation wastewater by highly concentrated activated sludge process coupled with UF membrane. Organic removal did not decrease significantly compared with continuous aeration mode. Denitrification contributed most to T-N removal compared with T-N losses in sample and sludge synthesis, and the optimal operating condition (30-min. aeration on and 30-min. aeration off) was obtained for carbon and nitrogen removals. Fluctuation patterns of DO and ORP in a cycle were observed and the activity of sludge was assessed by INT- dehydrogenase activity. Based on SEM observation, the rod-type bacteria were predominant compared with filamentous bacteria at higher MLSS concentration.
\end{abstract}

Key Words: membrane bioreactor, fermentation wastewater, intermittent aeration mode, highly concentrated activated sludge, nitrification, denitrification, sludge activity, ORP.

\section{INTRODUCTION}

Nutrient removal becomes more and more important in wastewater treatment due to the more stringent effluent criteria ${ }^{1}$. Biological nitrification and denitrification are increasingly popular options in activated sludge processes because of the associated economic advantages. Recent development of ultrafiltration (UF) process has given rise to new techniques for wastewater treatment, such as membrane bioreactor that makes use of both biological treatment and ultrafiltration separation of suspended solids. Its advantages can be seen elsewhere ${ }^{1-6}$. The UF membrane process enables retention of high biomass concentration in the reactor, i.e. the process can be operated with quite long sludge retention time (SRT). Furthermore, reactions which are carried out by organisms having a very slow growth rate, such as nitrification, can also function well at high loading rate $^{7}$.

In our previous study, a single-stage, single-sludge bioreactor in high concentration of activated sludge with rotary disk type UF membrane was used to treat high strength fermentation wastewater in continuous aeration condition ${ }^{8)}$. Almost $100 \%$ ammonia nitrogen was oxidized and high nitrification was obtained. However, denitrification was inhibited by the high DO concentration, and total nitrogen (T-N) removal efficiency was only around $11.6 \%$. Therefore, in order to improve $\mathrm{T}-\mathrm{N}$ removal, intermittent aeration mode 


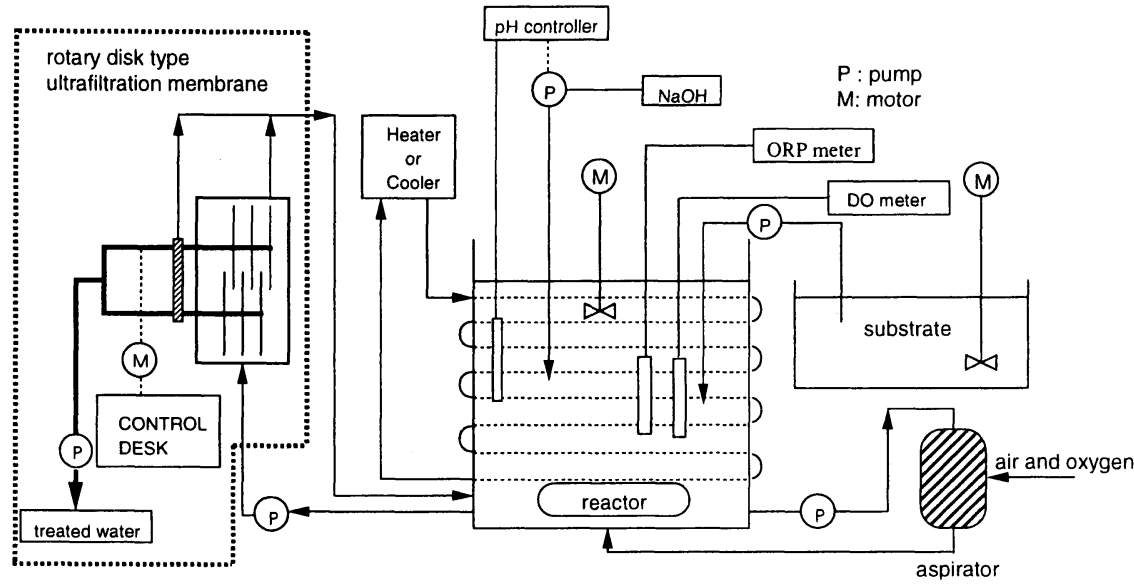

Fig.1 Schemetic diagram of experimental system.

of highly concentrated activated sludge bioreactor is selected because of its high biodegradability, slight $\mathrm{pH}$ variation in the reactor, cost saving and easy control ${ }^{7,9)-12)}$.

Ohba and Sakai developed a single-stage intermittent aeration system aiming to complete nitrification, promote denitrification to keep effluent $\mathrm{pH}$ neutral by intermittent aeration, and to equalize the flow to sedimentation tanks for sewage treatment plants of small communities ${ }^{11}$. High removal efficiencies of soluble nitrogen and COD were obtained with intermittent aeration in membrane separation activated sludge process with $3000 \mathrm{mg} / \mathrm{l}$ of MLSS concentration for artificial wastewater treatment similar to the quality of municipal sewage by Somiya et $\mathrm{al}^{10)}$. In this study, various intermittent aeration modes (according to the control of aeration time and non-aeration time) were carried out to improve denitrification as well as organic removal of high strength fermentation wastewater by highly concentrated activated sludge process. The performances of different operating conditions were investigated. Emphasis was given on the evaluation of the effect of intermittent aeration mode on the allocation of total nitrogen, and the specific nitrification rate and denitrification rate were calculated according to nitrogen balance. Variations of DO and oxidation - reduction potential (ORP) in one cycle in the reactor at different intermittent aeration modes were observed. Finally, the activities of sludge were assessed by 2 -( $p$-iodophenyl)-3-(p-nitrophenyl)5 -phenyl tetrazolium chloride (INT) - dehydrogenase activity, and the structure of sludge was observed by scanning electron microscope (SEM) throughout the experiment.

\section{MATERIALS AND METHODS}

\section{(1) System Configuration}

A schematic diagram of the lab-scale experimental apparatus employed in this study is shown in Fig.1. The unit consisted of a cylindrical bioreactor that had a working volume of 30 liters and a rotary disk type UF membrane separator with a volume of 10 liters. Membrane made of polysulfone with a cutoff 750,000 molecular weight and $0.30 \mathrm{~m}^{2}$ of total surface area provided by Hitachi Plant Engineering \& Construction Co., Ltd. was used in this study ${ }^{3)}$. This module consisted of two shafts in which each was fitted with three disks of $210 \mathrm{~mm}$ in diameter. One set of disks was engaged with the adjoining set of disks on the other shaft.

$1 \mathrm{~N}-\mathrm{NaOH}$ was added automatically to keep $\mathrm{pH}$ in the range of 6.8-7.2. Temperature of the liquid in the reactor was controlled to be in the range of $22-32^{\circ} \mathrm{C}$. The experiment was conducted with continuous influent, and effluent was intermittently withdrawn under 1 minute on and 9 minutes off operation mode by a suction pump. At the disk peripheral velocity of $2.7 \mathrm{~m} / \mathrm{s}$, the system was able to maintain the flux of $0.41-0.47 \mathrm{~m} / \mathrm{d}$ and the transmembrane pressure of 25 $36 \mathrm{kPa}$ for approximately two months. Then washing of membrane was performed in a long-term filtration, and sodium hypochlorite solution with a concentration of $100 \mathrm{mgCl}_{2} / \mathrm{l}$ was circulated through the UF membrane module for about 24 hours. After the washing, the flux of membrane recovered almost 
Table 1 Compositions of wastewater.

\begin{tabular}{cc}
\hline Parameter & Concentration \\
\hline $\mathrm{TOC}, \mathrm{mg} / \mathrm{l}$ & 98600 \\
$\mathrm{COD}_{\mathrm{Cr}}, \mathrm{mg} / \mathrm{l}$ & 247000 \\
$\mathrm{BOD}_{5}, \mathrm{mg} / \mathrm{l}$ & 164350 \\
$\mathrm{~T}-\mathrm{N}, \mathrm{mg} / \mathrm{l}$ & 35700 \\
$\mathrm{NH}_{4}-\mathrm{N}, \mathrm{mg} / \mathrm{l}$ & 13600 \\
$\mathrm{NO}_{2,3}-\mathrm{N}, \mathrm{mg} / \mathrm{l}$ & negligible \\
$\mathrm{SO}_{4}{ }^{2-}, \mathrm{mg} / \mathrm{l}$ & 21400 \\
$\mathrm{pH}$ & 5.3 \\
\hline
\end{tabular}

completely, and the transmembrane pressure recovered to about $95 \%$ of the first time.

\section{(2) Influent}

High concentration wastewater from a fermentation plant was used in this study. Its compositions are summarized in Table 1. It was stored at $4^{\circ} \mathrm{C}$ until use. Before being fed to the reactor, it was diluted with tap water to a desired TOC concentration.

\section{(3) Operating Conditions}

Seeding sludge was taken from the municipal wastewater treatment plant in Ube City, Yamaguchi, Japan. The acclimatization of activated sludge was carried out with successive addition of fermentation wastewater by gradually increasing TOC concentration. Finally, the biomass acclimatization was achieved when steady removals of TOC, $\mathrm{COD}_{\mathrm{Cr}}, \mathrm{NH}_{4}{ }^{-}$ $\mathrm{N}$ (over 90\%) were obtained, and MLSS, MLVSS concentrations in the reactor remained relatively unchanged. From then on, the experiment began as 0 day. The quantity of treated wastewater was $15 \mathrm{l} /$ day. Hydraulic retention time (HRT) of the system was 2.67 days.

\section{(4) Scanning Electron Microscope (SEM) and Microscopic Observation}

The samples of activated sludge for microscopic observation were fixed in $0.1 \mathrm{M}$ phosphate buffer ( $\mathrm{pH}=7.0$ ) containing $2.5 \%$ glutaraldehyde for 24 hours and dehydrated with a graded series $(50 \%, 70 \%, 80 \%$, $90 \%, 95 \%, 99.5 \%$ ) of ethanol solutions. Then ethanol was replaced with 2-methyl-2-propanol solution. The samples were subsequently dried overnight by JFD300 freeze dryer (JEOL Co., Japan) and sputter-coated with gold by E-1020 ion sputter (Hitachi, Ltd. Tokyo Japan). SEM microphotographs were taken with Hitachi S-2300 scanning electron microscope.

\section{(5) Analysis}

Total organic carbon (TOC) concentration in liquid
Table 2 Operational conditions.

\begin{tabular}{|c|c|c|c|}
\hline phase & run1 (days) & run2(days) & operation modes \\
\hline 1 & 20 & 20 & continuous aeration \\
\hline 2 & 18 & 19 & $10 \mathrm{~min}$ on $-10 \mathrm{~min}$ off \\
\hline 3 & 24 & 32 & $30 \mathrm{~min}$ on- $30 \mathrm{~min}$ off \\
\hline 4 & 24 & 26 & $60 \mathrm{~min}$ on $-30 \mathrm{~min}$ off \\
\hline
\end{tabular}

Table 3 Characteristics of influent.

\begin{tabular}{ccc}
\hline parameters & run 1 & run 2 \\
\hline $\mathrm{TOC}$ & $1160-1600(1360)$ & $1950-2540(2150)$ \\
$\mathrm{COD}_{\mathrm{Cr}}$ & $2180-4020(3190)$ & $4670-6430(5445)$ \\
$\mathrm{NH}_{4}-\mathrm{N}$ & $235-350(252)$ & $390-540(460)$ \\
$\mathrm{T}-\mathrm{N}$ & $370-560(457)$ & $490-750(630)$ \\
\hline
\end{tabular}

unit: $\mathrm{mg} / \mathrm{l}$, Data in parenthesis is the average.

samples was determined by a Shimadzu model TOC5000 analyzer. $\mathrm{NO}_{2.3}-\mathrm{N}$ concentration was determined by ionic chromatography (UV-8000, Tosoh Co., Ltd.). T-N was measured by a T-N analyzer (GCT-16N, Sumitomo Chemical Co., Ltd. \& GC-8APT, Shimadzu Co., Ltd.), whereas $\mathrm{COD}_{\mathrm{Cr}}, \mathrm{NH}_{4}-\mathrm{N}$, MLSS, MLVSS were determined according to Standard Methods ${ }^{131}$. DO, ORP, pH were measured on-line using probes. INT-dehydrogenase activity was determined according to Logue, et al $^{14)}$.

\section{RESULTS AND DISCUSSION}

\section{(1) Operational Performance}

The bench-scale experiments were conducted with two operating conditions: run 1 with an average TOC loading of $0.51 \mathrm{kgTOC} / \mathrm{m}^{3} /$ day at $30 \pm 2{ }^{\circ} \mathrm{C}$ and run2 with $0.81 \mathrm{kgTOC} / \mathrm{m}^{3} / \mathrm{day}$ at $24 \pm 2{ }^{\circ} \mathrm{C}$. During the experiment, no sludge was wasted except samples. The volume of samples $(50-100 \mathrm{ml} / \mathrm{day})$ from the reactor was little compared with the volume of total activated sludge in the reactor and membrane module. The practical average sludge retention time (SRT) was between 400-800 days when sampling was considered. The operating conditions and the influent characteristics of experiment are shown in Table $\mathbf{2}$ and Table 3, respectively.

\section{a) Performance in Run1}

The experiment of run 1 lasted for 83 days. After 20 days of operation under continuous aeration in phase 1 , intermittent aeration modes were applied to the system in order to provide anoxic condition for 

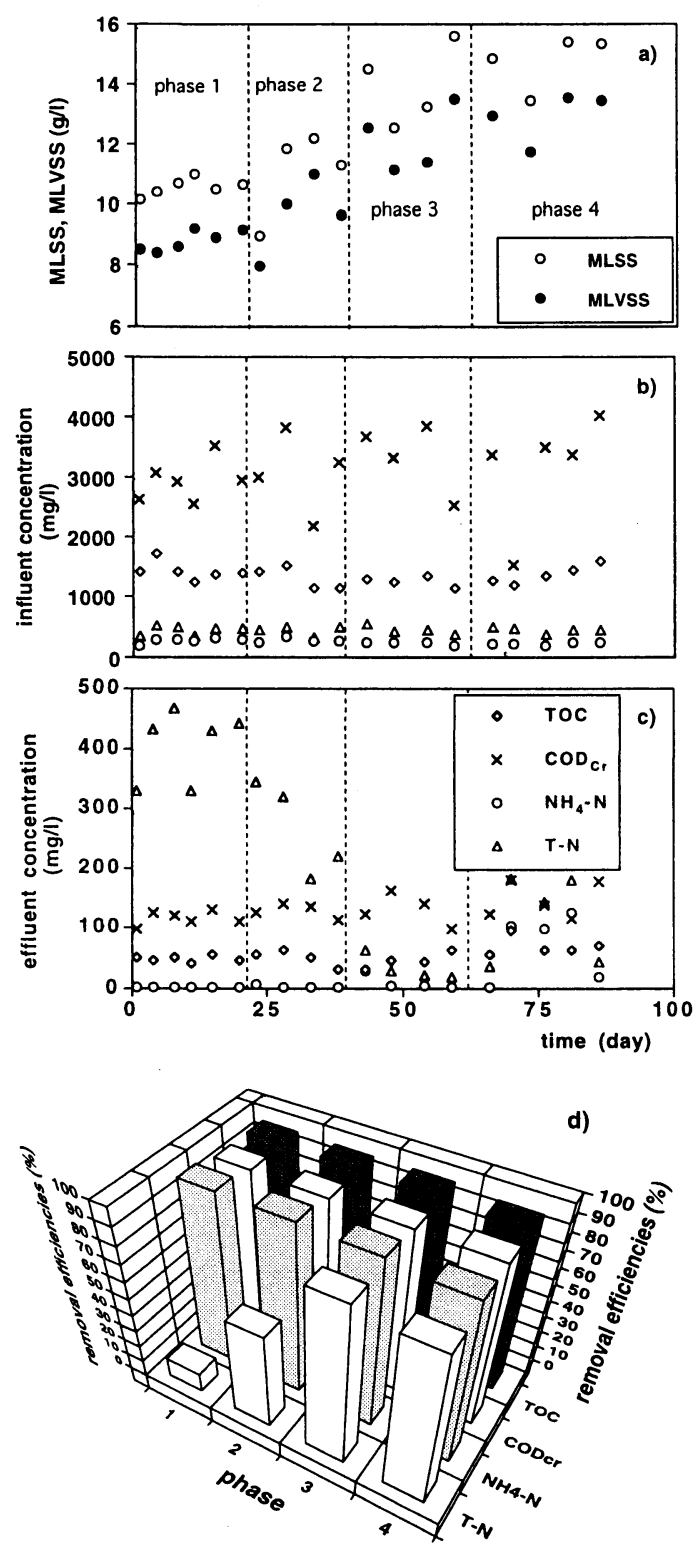

Fig.2 Performance of run1.

a) MLSS, MLVSS concentrations versus time

b) influent concentration versus time

c) effluent concentration versus time

d) removal efficiencies in phase 1-4

denitrification in phase 2-4. Phase 2 lasted for 18 days, and phases 3 and 4 lasted for 24 days. In the aeration period, oxygen was supplied to maintain DO of 1.5$2.5 \mathrm{mg} / 1$. MLSS, MLVSS concentrations in the reactor, and the influent and effluent performances are shown in Fig.2. After introducing anoxic condition to the system, MLSS and MLVSS concentrations increased gradually from $10.6 \mathrm{~g} / \mathrm{l}$ and $9.0 \mathrm{~g} / \mathrm{l}$ at the beginning of phase 2 to $14.8 \mathrm{~g} / \mathrm{l}$ and $12.9 \mathrm{~g} / \mathrm{l}$ at the end of phase 4 corresponding to the change of sludge-mass-balance. At the 65th day in phase $4, \mathrm{pH}$ controller broke and $\mathrm{pH}$ in the reactor increased to 10.5 . Then $\mathrm{HCl}$ was added to the reactor and the effluent quality finally recovered on the 82 nd day. The removal efficiencies of phase 1 to 4 at the end of each phase are also shown in Fig.2 (data in recovering period was not used for calculation in phase 4). TOC and CODcr in the effluent were less than $96 \mathrm{mg} / \mathrm{l}$ and $180 \mathrm{mg} / \mathrm{l}$ in all phases with the removal efficiencies over $92 \%$ and $94 \%$, respectively, even during recovering period in phase 4. $\mathrm{NH}_{4}-\mathrm{N}$ was removed almost completely in phase 1 4 at general condition except during the high $\mathrm{pH}$ period in phase 4 which had a great influence on its removal and resulted in a high effluent $\mathrm{NH}_{4}-\mathrm{N}$ concentration of $110 \mathrm{mg} / \mathrm{l}$. This was because Nitrosomonas that oxidized $\mathrm{NH}_{4}-\mathrm{N}$ to nitrite was inhibited at high $\mathrm{pH}$ condition. T-N removal efficiencies in phase 1-4 were $10 \%, 40 \%, 87 \%$ and $86 \%$, respectively. The average $\mathrm{NO}_{2,3}-\mathrm{N}$ concentrations in the effluent in phase 1,2 were 334 and $170 \mathrm{mg} / \mathrm{l}$, respectively, and were not detected in phase 3 and 4 which indicated that all nitrified nitrogen was denitrified in phase 3 and 4 .

\section{b) Performance of Run2}

The duration of run2 was 97 days with an average TOC loading of $0.81 \mathrm{kgTOC} / \mathrm{m}^{3} /$ day. Since the experiment was conducted in winter, the temperature of the liquid decreased to $24 \pm 2{ }^{\circ} \mathrm{C}$. The experiment was conducted under continuous aeration condition after the change of TOC loading until a relative steadystate condition was obtained. The operation of phase 1-4 lasted for 20, 19, 32 and 26 days, respectively. DO was maintained at $2.0-3.0 \mathrm{mg} / \mathrm{l}$ in the aeration period. MLSS, MLVSS concentrations in the reactor, effluent quality and removal efficiencies at the end of each phase are shown in Fig.3. As in run 1, MLSS and MLVSS increased gradually from $10.1 \mathrm{~g} / \mathrm{l}$ and $8.5 \mathrm{~g} / \mathrm{l}$ at the beginning of phase 2 to $14.6 \mathrm{~g} / \mathrm{l}$ and $12.6 \mathrm{~g} / \mathrm{l}$ at the end of phase 4 . TOC and COD $\mathrm{Cr}$ concentrations in the effluent were less than $130 \mathrm{mg} / \mathrm{l}$ and $300 \mathrm{mg} / \mathrm{l}$, respectively, in all phases with both TOC and $\mathrm{COD}_{\mathrm{C}}$ removal efficiencies over $94 \%$. $\mathrm{NH}_{4}-\mathrm{N}$ removal was almost complete with the $\mathrm{NH}_{4}-\mathrm{N}$ concentration in the effluent less than $3.5 \mathrm{mg} / \mathrm{l}$. T-N removal efficiencies in phase 1 to 4 at the end of each phase were $22 \%$, $78 \%, 88 \%$ and $82 \%$, respectively. The average $\mathrm{NO}_{2.3-}$ $\mathrm{N}$ concentrations in the effluent in phase 1-4 were 366 , $71,3.6$ and $2.7 \mathrm{mg} / \mathrm{l}$, respectively.

Of particular interest was the increase of MLSS 

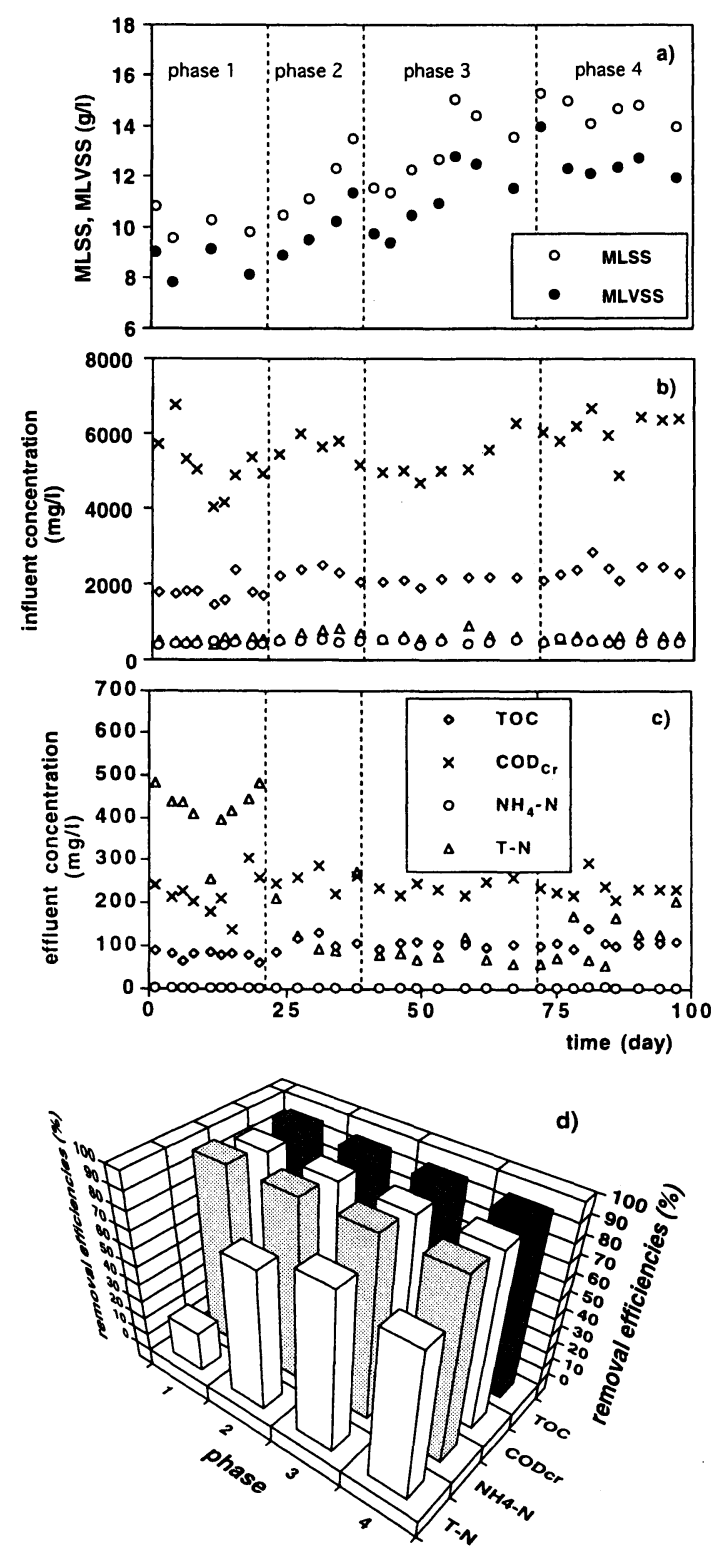

Fig.3 Performance of run2.

a) MLSS, MLVSS concentrations versus time

b) influent concentration versus time

c) effluent concentration versus time

d) removal efficiencies in phase 1-4

and MLVSS concentrations after introducing anoxic condition to the system in both run 1 and run2. The increase of MLSS and MLVSS concentrations is related to the growth rate of biomass through the degradation of substrate, wasted sludge and decay of biomass. The decay rate of biomass is related not only to biomass concentration, but also to DO concentration in the reactor, and it is inhibited in the absence of DO Therefore, after the incursion of anoxic operating condition to the system, the rate of biomass decay decreased as compared with that in continuous aeration condition. In addition, influent concentration of substrate increased slightly resulting in the increase of MLSS, MLVSS concentrations which was corresponding to the change of sludge-mass-balance. Although the average TOC loading in run2 was higher than that in run1, MLSS and MLVSS concentrations in run2 were not higher than those in run1. This was probably due to the lower biomass growth rate under slightly low temperature condition in run 2 compared with that in run1.

\section{(2) Nitrification and Denitrification a) Allocation of Nitrogen}

The influent of T-N can be allocated as following four parts:

\section{I . T-N loss in the effluent}

This can be calculated by T-N concentration in the effluent.

\section{II . T-N deposited in sludge in the reactor}

MLSS concentration increased gradually from phase 2 to 3 and nitrogen was synthesized in biomass. Here, the value of the total nitrogen content of sludge $9.65 \%$, was used for calculation ${ }^{15)}$

\section{III . T-N waste in sample}

In the whole experiment, no sludge was wasted except the samples. Samples included T-N in liquid as well as in solid phases. This part can be calculated according to I and II. Sample volume of $75 \mathrm{ml} / \mathrm{day}$ was used for estimation.

N . T-N loss by denitrification

This can be calculated from $\mathrm{T}-\mathrm{N}$ mass balance. Here, it must be noticed that disappeared $\mathrm{N}_{2} \mathrm{O}$ was not taken into account and complete denitrification was assumed.

The results of allocation of nitrogen in run 1 and run2 at phase 1-4 are listed in Table 4. T-N loss in sampling was very low, in an average of $1.3 \%$ in run 1 and $1.0 \%$ in run 2 . T-N deposited in sludge from phase 2 to 3 during the increase of MLSS concentration were in the average of $4.1 \%$ in run 1 and $2.4 \%$ in run 2 . The significant changes of T-N were found in the effluent and in denitrification. T-N losses by denitrification from phase 1 to 4 were $9.9 \%, 36.0 \%, 87.5 \%$, and $85.8 \%$ in run 1 , and were $21.5 \%, 76.1 \%, 85.0 \%$ and $77.8 \%$ in run2, respectively. The high denitrification was characterized by lower T-N concentration in the effluent obtained in phase 3 of both runs. 
Table 4 Allocation of nitrogen.

\begin{tabular}{|c|c|c|c|c|c|c|}
\hline $\begin{array}{l}\text { Run } \\
\text { No. }\end{array}$ & phase & $\begin{array}{l}\text { TN in } \\
\text { effluent } \\
\text { gN/day }\end{array}$ & \begin{tabular}{|c}
$\begin{array}{c}\text { TN deposited } \\
\text { in sludge } \\
\mathrm{gN} / \text { day }\end{array}$ \\
\end{tabular} & $\begin{array}{l}\text { TN in } \\
\text { sample } \\
\text { gN/day }\end{array}$ & $\begin{array}{c}\text { TN loss by } \\
\text { denitrification } \\
\mathrm{gN} / \text { day }\end{array}$ & $\begin{array}{c}\mathrm{TN} \text { in } \\
\text { influent } \\
\mathrm{gN} / \mathrm{day} \\
\end{array}$ \\
\hline \multirow{4}{*}{1} & 1 & $\begin{array}{c}6.07 \\
(88.74 \%)\end{array}$ & $\begin{array}{c}0 \\
(0 \%)\end{array}$ & $\begin{array}{c}0.09 \\
(1.35 \%)\end{array}$ & $\begin{array}{c}0.68 \\
(9.91 \%)\end{array}$ & $\begin{array}{c}6.84 \\
(100 \%)\end{array}$ \\
\hline & 2 & $\begin{array}{c}4.01 \\
(58.63 \%)\end{array}$ & $\begin{array}{c}0.28 \\
(4.10 \%)\end{array}$ & $\begin{array}{c}0.09 \\
(1.26 \%)\end{array}$ & $\begin{array}{c}2.46 \\
(36.02 \%)\end{array}$ & $\begin{array}{c}6.84 \\
(100 \%)\end{array}$ \\
\hline & 3 & $\begin{array}{c}0.49 \\
(7.12 \%)\end{array}$ & $\begin{array}{c}0.28 \\
(4.07 \%)\end{array}$ & $\begin{array}{l}0.09 \\
(1.31 \%)\end{array}$ & $\begin{array}{c}6.02 \\
(87.50 \%)\end{array}$ & $\begin{array}{c}6.88 \\
(100 \%)\end{array}$ \\
\hline & 4 & $\begin{array}{c}0.6 \\
(8.71 \%) \\
\end{array}$ & $\begin{array}{c}0.28 \\
(4.06 \%) \\
\end{array}$ & $\begin{array}{c}0.1 \\
(1.45 \%)\end{array}$ & $\begin{array}{c}5.91 \\
(85.78 \%)\end{array}$ & $\begin{array}{c}6.89 \\
(100 \%) \\
\end{array}$ \\
\hline \multirow{4}{*}{2} & 1 & $\begin{array}{c}6.27 \\
(77.37 \%)\end{array}$ & $\begin{array}{c}0 \\
(0 \%)\end{array}$ & $\begin{array}{c}0.09 \\
(1.11 \%)\end{array}$ & $\begin{array}{c}1.74 \\
(21.52 \%)\end{array}$ & $\begin{array}{c}8.1 \\
(100 \%)\end{array}$ \\
\hline & 2 & $\begin{array}{c}2.36 \\
(21.03 \%)\end{array}$ & $\begin{array}{c}0.24 \\
(2.14 \%)\end{array}$ & $\begin{array}{c}0.09 \\
(0.76 \%)\end{array}$ & $\begin{array}{c}8.55 \\
(76.08 \%)\end{array}$ & $\begin{array}{l}11.24 \\
(100 \%)\end{array}$ \\
\hline & 3 & $\begin{array}{l}1.17 \\
(11.70 \%)\end{array}$ & $\begin{array}{l}0.24 \\
(2.40 \%)\end{array}$ & $\begin{array}{c}0.09 \\
(0.86 \%)\end{array}$ & $\begin{array}{c}8.5 \\
(85.04 \%)\end{array}$ & $\begin{array}{c}10.0 \\
(100 \%)\end{array}$ \\
\hline & 4 & $\begin{array}{c}1.73 \\
(18.57 \%)\end{array}$ & $\begin{array}{c}0.24 \\
(2.57 \%)\end{array}$ & $\begin{array}{c}0.1 \\
(1.06 \%)\end{array}$ & $\begin{array}{c}7.27 \\
(77.81 \%)\end{array}$ & $\begin{array}{c}9.34 \\
(100 \%)\end{array}$ \\
\hline
\end{tabular}

( ) are allocation percentages of total nitrogen

\section{b) Nitrification and Denitrification Ratios}

During nitrification, organic nitrogen and $\mathrm{NH}_{4}-\mathrm{N}$ were partly nitrified to $\mathrm{NO}_{2,3}-\mathrm{N}$. Whilst, during denitrification, $\mathrm{NO}_{2,3}-\mathrm{N}$ was denitrified to nitrogen gas. Here, nitrification and denitrification ratios based on total nitrogen were calculated according to the allocation of nitrogen, T-N, $\mathrm{NH}_{4}-\mathrm{N}$ and $\mathrm{NO}_{2,3}-\mathrm{N}$ concentrations in the influent and effluent. The results are shown in Fig.4. In phase 2 of both runs, nitrification ratio had a slight decrease which might be due to the sudden incursion of anoxic condition. Later, however, it gradually increased and recovered to the original level in phases 3 and 4 compared with that in phase 1 . However, denitrification ratio increased remarkably in phase 2 to about $50 \%$ in run 1 and to about $80 \%$ in run2. In phases 3 and 4 of both runs, denitrification ratio increased and its value was almost the same to nitrification ratio, which indicated that all nitrified nitrogen was denitrified and denitrification was limited by nitrification. During the recovering period from the failure of $\mathrm{pH}$ control in phase 4 of run 1 , nitrification and denitrification were significantly influenced and both decreased to $58 \%$. This was also demonstrated by other researchers that nitrification was inhibited under high $\mathrm{pH}$ condition ${ }^{16), 17)}$.

\section{c) Influence of T-N Loading on T-N Removal in Different Phases}

T-N loading rate varied between $0.13 \sim 0.21 \mathrm{kgN} /$ $\mathrm{m}^{3} /$ day in run 1 and $0.18 \sim 0.35 \mathrm{kgN} / \mathrm{m}^{3} /$ day in run2 at the average of $0.17 \mathrm{kgN} / \mathrm{m}^{3} /$ day and $0.23 \mathrm{kgN} / \mathrm{m}^{3} /$ day, respectively. T-N removal rates in the whole experimental period versus T-N loading rates is shown in Fig.5. During continuous aeration period in phase 1 , T-N removal rate was quite lower, and the maximum $\mathrm{T}-\mathrm{N}$ removal rate was lower than $0.1 \mathrm{kgN} / \mathrm{m}^{3} /$ day. After incursion of anoxic operation, $\mathrm{T}-\mathrm{N}$ removal rate

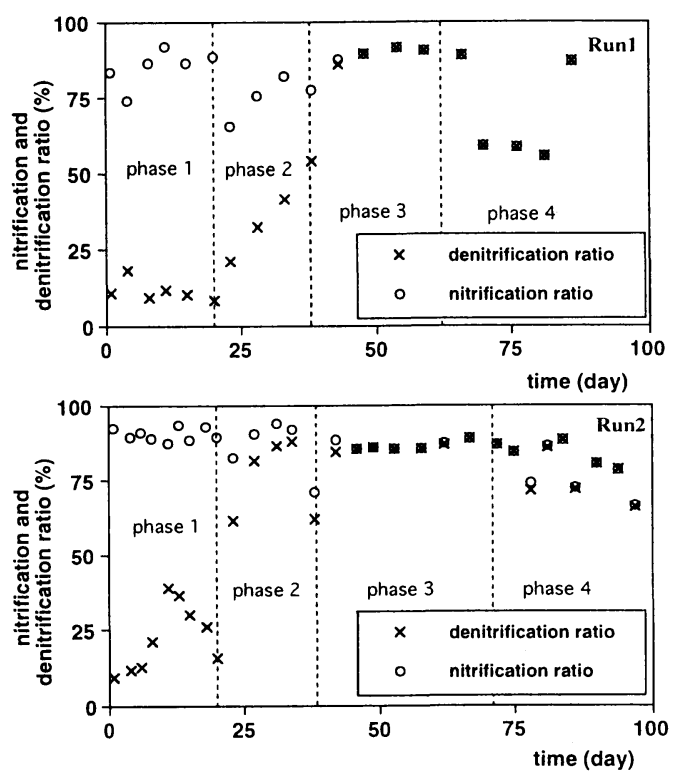

Fig.4 The ratios of nitrification and denitrification in run I and run2.

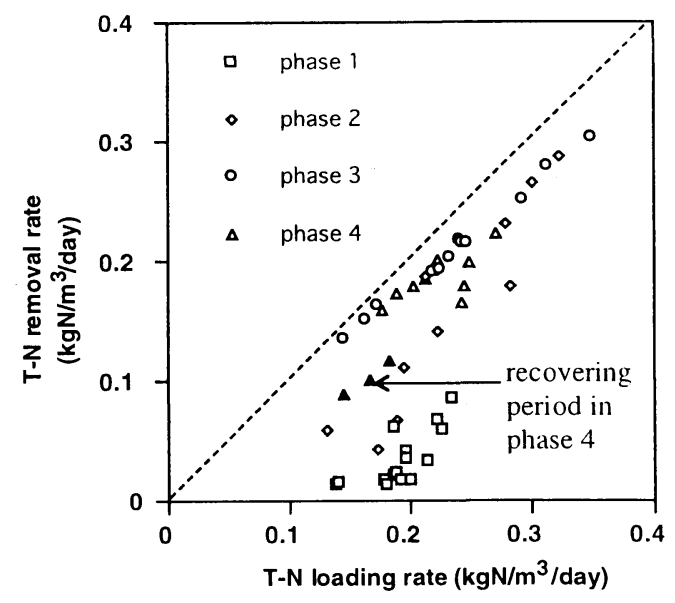

Fig.5 T-N removal rates in phase 1-4 of run l and run2 versus $\mathrm{T}-\mathrm{N}$ loading rates.

increased proportionally to the T-N loading rate, and $\mathrm{T}-\mathrm{N}$ removal rate in phase 3 was the nearest one to the $\mathrm{T}-\mathrm{N}$ loading rate comparing with those in phases 2 and 4 . During the recovering period in phase 4 due to the failure of $\mathrm{pH}$ control, $\mathrm{T}-\mathrm{N}$ removal rate decreased significantly and deviated from the linear part remarkably. Fig.5 also indicated that T-N removal capacity did not reach its limit even at $0.35 \mathrm{kgN} / \mathrm{m}^{3} /$ day (in phase 3) of $\mathrm{T}-\mathrm{N}$ loading rate under this experimental condition. This probably contributed to the high concentration of activated sludge in UF membrane bioreactor and most nitrifiers having slow 
growth rate held by UF membrane compared with conventional activated sludge process.

\section{d) Specific Nitrification and Denitrification Rates}

Generally, organic nitrogen is converted to ammonia nitrogen by ammonification. During nitrification, ammonia nitrogen is nitrified to $\mathrm{NO}_{2,3-}$ $\mathrm{N}$. Whilst, during denitrification, $\mathrm{NO}_{2,3}-\mathrm{N}$ is denitrified to nitrogen gas. Based on total nitrogen mass balance, the specific nitrification rate (SNR) and specific denitrification rate (SDNR) were calculated according to the following equations:

$$
\begin{aligned}
& \mathrm{r}_{\mathrm{DN}}=\frac{\left(\mathrm{TN}_{1}-\mathrm{TN}_{2}\right) \cdot \mathrm{Q}-\mathrm{r}_{\mathrm{MLSS}} \cdot \mathrm{V} \cdot 9.65 \%}{\mathrm{~V} \cdot \mathrm{MLVSS} \cdot 24} \\
& \mathrm{r}_{\mathrm{N}}=\mathrm{r}_{\mathrm{DN}}+\frac{\left[\left(\mathrm{NO}_{\mathrm{x}}-\mathrm{N}\right)_{2}-\left(\mathrm{NO}_{\mathrm{x}}-\mathrm{N}\right)_{1}\right] \cdot \mathrm{Q}}{\mathrm{V} \cdot \mathrm{MLVSS} \cdot 24}
\end{aligned}
$$

where,

$\mathrm{r}_{\mathrm{DN}}$ : the average specific denitrification rate $(\mathrm{gN} /$

$\mathrm{kgVSS} / \mathrm{hr}$ )

$\mathrm{r}_{\mathrm{N}}$ : the average specific nitrification rate (gN/kgVSS/ hr)

$\mathrm{TN}_{1}$ : T-N concentration in influent $(\mathrm{mg} / \mathrm{l})$

$\mathrm{TN}_{2}$ : T-N concentration in effluent $(\mathrm{mg} / \mathrm{l})$

$(\mathrm{NOx}-\mathrm{N})_{1}: \mathrm{NO}_{2,3}-\mathrm{N}$ concentration in influent $(\mathrm{mg} / \mathrm{l})$

$(\mathrm{NOx}-\mathrm{N})_{2}: \mathrm{NO}_{2,3}-\mathrm{N}$ concentration in effluent $(\mathrm{mg} / \mathrm{l})$

$\mathrm{Q}$ : volume of treated water per day (15 $\mathrm{l} /$ day $)$

$\mathrm{V}$ : reactor volume, cylindrical bioreactor $(301)$

+ membrane separator (10 l)

$\mathrm{r}_{\text {MLSS }}$ : the average increasing rate of MLSS in the reactor from phase 2 to 3 (run $1: 73 \mathrm{mg} / \mathrm{l} / \mathrm{day}$, run2: $61 \mathrm{mg} / \mathrm{l} /$ day)

MLVSS: MLVSS concentration in the reactor $(\mathrm{g} / \mathrm{l})$

9.65\%: total nitrogen content of sludge ${ }^{15)}$

The average SNR and SDNR in phase 1-4 of both runs are shown in Table 5. In both runs, SNR were between $0.51 \sim 1.02 \mathrm{gN} / \mathrm{kgVSS} / \mathrm{hr}$, and SDNR were between $0.27 \sim 0.91 \mathrm{gN} / \mathrm{kgVSS} / \mathrm{hr}$ except in phase 1 in which SDNR were much lower than $0.09 \mathrm{gN} /$ $\mathrm{kgVSS} / \mathrm{hr}$ in run 1 and $0.22 \mathrm{gN} / \mathrm{kgVSS} / \mathrm{hr}$ in run 2 . SNR did not vary greatly from phase 1 to phase 4 . However, SDNR increased significantly after the incursion of anoxic condition. In phase 2, SDNR increased to the half of SNR in run1 and about $90 \%$ of SNR in run2. In phases 3 and 4 , SDNR were almost the same to SNR and this indicated that nitrification was a limiting step which was in agreement with the results of
Table 5 The average specific nitrification and denitrification rates.

\begin{tabular}{c|c|c|c}
\hline \multicolumn{2}{c|}{ phase } & $\begin{array}{c}\text { SNR } \\
(\mathrm{gN} / \mathrm{kgVSS} / \mathrm{hr})\end{array}$ & $\begin{array}{c}\text { SDNR } \\
(\mathrm{gN} / \mathrm{kgVSS} / \mathrm{hr})\end{array}$ \\
\hline \multirow{4}{*}{ Run1 } & 1 & 0.69 & 0.09 \\
\cline { 2 - 4 } & 2 & 0.56 & 0.27 \\
\cline { 2 - 4 } & 3 & 0.53 & 0.53 \\
\cline { 2 - 4 } & 4 & 0.51 & 0.51 \\
\hline \multirow{4}{*}{ Run2 } & 1 & 0.88 & 0.22 \\
\cline { 2 - 4 } & 2 & 1.02 & 0.91 \\
\cline { 2 - 4 } & 3 & 0.81 & 0.81 \\
\cline { 2 - 4 } & 4 & 0.62 & 0.61 \\
\hline
\end{tabular}

Chiemchaisri, et $a l^{7)}$. On the other hand, the simultaneous nitrification and denitrification could be obtained in phases 3 and 4 by intermittent aeration mode.

The experiment demonstrated that the incursion of anoxic operating condition to the system indeed improved the nitrogen removal, and the organic carbon removal was not adversely influenced. High nitrogen removal (over $80 \%$ ) was obtained in phases 3 and 4 However, the longer aeration operation in phase $4(60$ min. aeration on - $30 \mathrm{~min}$. aeration off) would consume larger oxygen and increase operating cost. The optimal operating condition in phase 3 (30 min. aeration on $30 \mathrm{~min}$. aeration off) was obtained in this study due to the high efficiency of simultaneous carbon and nitrogen removals. The lower nitrogen removal in phase 2 might be due to the sudden change of operating condition from continuous aeration mode, and the experiment in phase 2 did not last enough longer. However, because of the rapid change between aerobic and anoxic operating conditions, aeration pump on and off modes changed quickly which probably resulted in bad condition for pump maintenance. Therefore, $30 \mathrm{~min}$. aeration on - $30 \mathrm{~min}$. aeration off can be concluded to be the optimal operating condition in this study for fermentation wastewater treatment by highly concentrated activated sludge process with membrane as a separator.

\section{(3) Characteristics of Operating Environment and Activated Sludge in the Reactor}

The investigations of DO and ORP variations in the reactor, activities of sludge and SEM observations were investigated in run2.

a) Variations of DO and ORP (all ORP data is with reference to $\mathrm{Ag} / \mathrm{AgCl}$ )

In phase 1 of run2, DO was maintained at $1.5 \sim$ $2.5 \mathrm{mg} / \mathrm{l}$. ORP in this phase was between $+100 \sim+140$ $\mathrm{mV}$. In phase $2-4$, anoxic condition was introduced to 

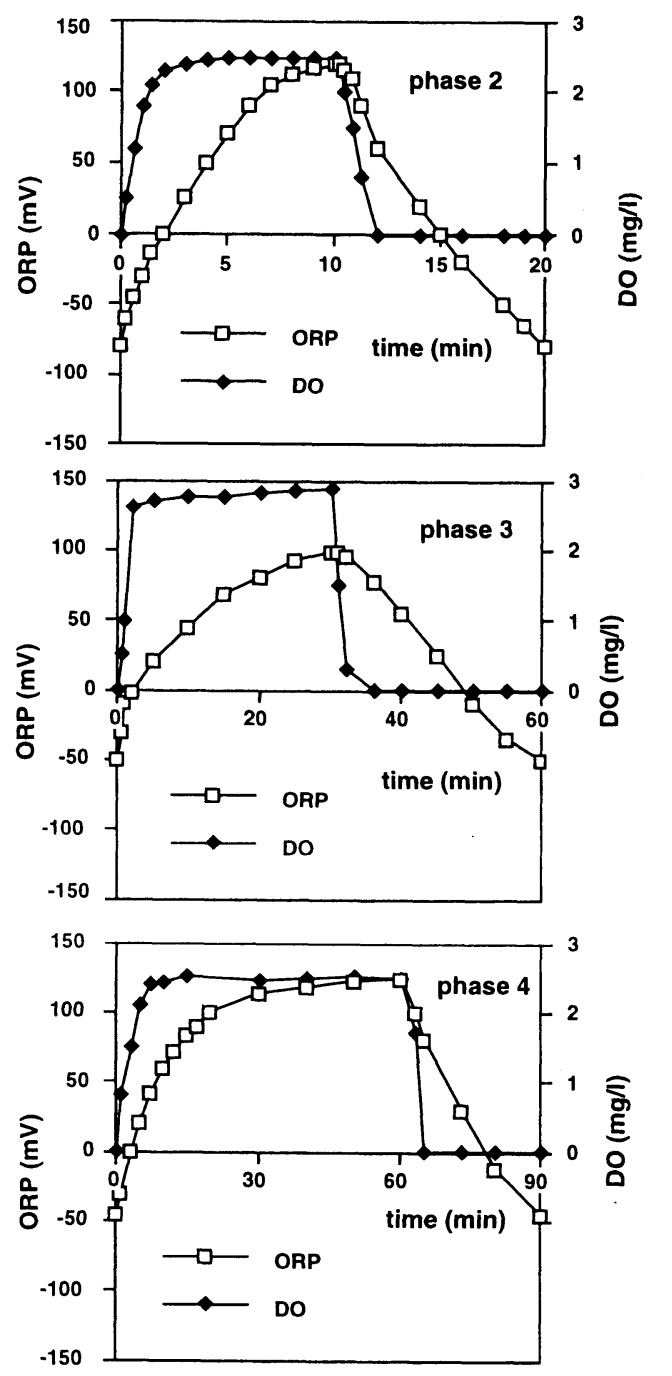

Fig.6 Fluctuation patterns of DO and ORP in one cycle in phase $2-4$.

the reactor. Fluctuation patterns of DO and ORP in one cycle in phase 2-4 are represented in Fig.6.

In phase 2 , the maximum $\mathrm{DO}$ in the reactor was about $2.5 \mathrm{mg} / 1$. After the stop of aeration pump, DO decreased quickly from 2.5 to $0 \mathrm{mg} / \mathrm{l}$ within about 2 minutes. ORP varied between $-80 \sim+120 \mathrm{mV}$. It increased during aeration condition and decreased significantly during non-aeration condition in one cycle.

In phase 3 , the maximum $\mathrm{DO}$ in the reactor was at $2.8 \mathrm{mg} / \mathrm{l}$. ORP varied between $-50 \sim+100 \mathrm{mV}$. The patterns of DO and ORP were almost the same to those in phase 2 .

In phase 4 , the time under aeration condition was

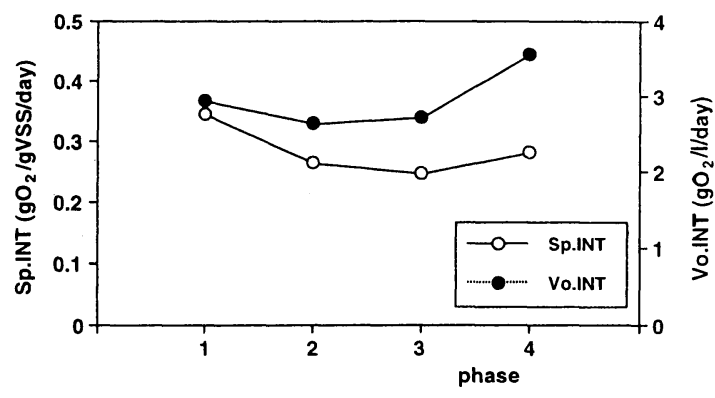

Fig.7 Activities of sludge in phase 1-4.

increased to 60 minutes. The maximum DO in the reactor was $2.5 \mathrm{mg} / \mathrm{l}$. ORP varied between $-45 \sim+120$ $\mathrm{mV}$. After the start-up of aeration, ORP increased gradually during the first 20 minutes, then it increased slowly until the aeration was stopped.

Although the patterns of DO and ORP in one cycle in phase 2 and 3 were almost the same, T-N removals were significantly different. The lower $\mathrm{T}-\mathrm{N}$ removal in phase 2 was probably because of the following two reasons: First, phase 2 was followed by phase I with continuous aeration mode and the denitrifier might not fit to the sudden change of environment, and the experimental period in phase 2 was probably too short. Second, a little lag-time might exist in denitrification.

In our studies, ORP varied between $-80 \sim+120$ $\mathrm{mV}$ during phase 2-4. It was in accordance to the results of Yuyama, et $a l^{l(8)}$ who reported that ORP was desirable to change from not less than $-100 \mathrm{mV}$ to more than $+100 \mathrm{mV}$ in a cycle in batch-activated sludge process for the removal of nitrogen. Koch and Oldham $^{19)}$ also suggested that ORP could be used as a unique and effective means in monitoring and controlling nitrate removal process.

\section{b) Activity of Sludge in the Reactor}

Due to high SRT (400-800 days) in this process and incursion of anoxic operating condition, the activity of sludge in the reactor is utmost important. The activity of highly concentrated activated sludge in phase 1-4 was assessed by INT- dehydrogenase activity ${ }^{(4), 20)}$, and the plot of activities in phase $1-4$ is shown in Fig.7.

The average specific activities in phase 1-4 were $0.34,0.26,0.25$ and $0.28 \mathrm{gO}_{2} / \mathrm{gVSS} /$ day, respectively. After introducing anoxic operating condition into the system, the specific activity decreased. This might be due to the sudden change of environment, or the increase of MLVSS concentration in the reactor as the previous research has shown that the specific activity of sludge would decrease slightly with the increase of MLVSS concentration in continuous aeration 
condition in highly concentrated activated sludge bioreactor system ${ }^{8)}$. In phase 4 , the activity had a slight increase and this was probably because of the time increase of aerobic condition with reference to anoxic condition. On the other hand, the volumetric activities of phase $1-4$ were $2.93,2.64,2.72$ and $3.56 \mathrm{gO}_{2} / 1 /$ day, respectively, and the volumetric activities in phases 2 and 3 did not decrease greatly compared with that in phase 1 . The maximum volumetric activity was obtained in phase 4 . Accordingly, it can be concluded that the whole activity of sludge in the reactor was not influenced significantly after the incursion of anoxic operation and high concentration of activated sludge might be responsible for the high ability of shock adsorption.

Although the fermentation wastewater included high $\mathrm{SO}_{4}{ }^{2-}$ concentration, the effluent quality was not adversely influenced. This was probably because no complete anaerobic condition occurred in the reactor. During the intermittent aeration operation, the minimum ORP was not lower than $-80 \mathrm{mV}$, and the environment in the reactor changed between aerobicanoxic condition. Hence, no hydrogen sulfide was produced in the reactor, and the process was not inhibited $^{21)}$.

On the other hand, the fermentation wastewater contained lower inorganic materials. Inorganic compounds did not disrupt treatment performance when sludge was almost completely retained in the reactor. $\mathrm{pH}$ of the liquid in the reactor was maintained between 6.8-7.2, therefore no $\mathrm{NH}_{3}$ was produced to inhibit biomass even through the fermentation wastewater included high $\mathrm{NH}_{4}-\mathrm{N}$ concentration ${ }^{21)}$. Also, the high removal efficiencies of TOC and $\mathrm{NH}_{4}$ $\mathrm{N}$ during the entire experiment indicated that inhibitors or toxic materials did not accumulate in the reactor due to fewer heavy metal ions or toxic materials contained in the fermentation wastewater.

Due to high concentration of activated sludge in the reactor, the biodegradability of organic materials was improved ${ }^{8)}$. The metabolic products of sludge in liquid such as protein $(170 \mathrm{mg} / \mathrm{l})$ and polysaccharide $(30 \mathrm{mg} / \mathrm{l})$ remained high compared with those (protein, $24 \mathrm{mg} / \mathrm{l}$; polysaccharide, $12 \mathrm{mg} / \mathrm{l}$ ) in conventional activated sludge process. However, they did not accumulate unlimitedly and maintained almost the same during the experiment.

\section{c) SEM Observations of Activated Sludge}

The activated sludge was observed based on SEM observations. There were no significant differences with those in our former studies ${ }^{8)}$ that the filamentous
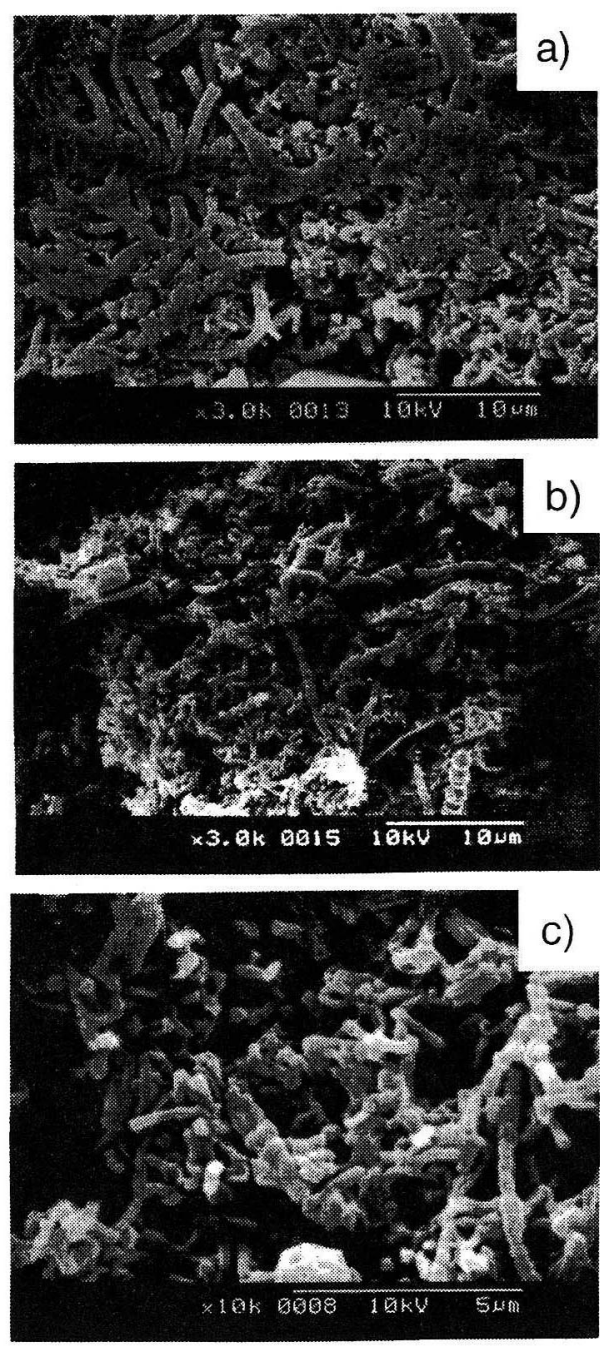

Fig.8 The SEM photographs of sludge in different conditions

a). in continuous aeration condition in former study ${ }^{(8)}$.

MLSS $=13 \mathrm{~g} / \mathrm{l}, \times 3000$

b). in intermittent aeration condition in this study in phase

3 of run 2, MLSS $=12 \mathrm{~g} / \mathrm{l}, \times 3000$

c). in intermittent aeration condition in this study in phase

3 of run 2, MLSS $=12 \mathrm{~g} / \mathrm{l}, \times 10000$

bacteria were predominant at lower MLSS concentration and the coccus-like or rod-type bacteria were prevailing at higher MLSS concentration (over $10 \mathrm{gMLSS} / \mathrm{l}$ ). The comparisons of SEM photographs of sludges in different conditions are shown in Fig.8. The rod-type bacteria were predominant compared with filamentous bacteria. This also indicated that the type of bacteria did not significantly change when anoxic condition was introduced to the system. 


\section{CONCLUSIONS}

The following conclusions can be drawn from the results of this experiment.

(1) Various intermittent aeration modes can be applied to treat fermentation wastewater by highly concentrated activated sludge UF membrane bioreactor process. Organic removal did not significantly decrease when anoxic condition was introduced to the system, however, T-N removal increased remarkably.

(2) Denitrification in anoxic condition contributed most for T-N removal compared with T-N losses in samples and biomass synthesis. T-N removal capacity did not reach its limit even at $0.35 \mathrm{kgN} / \mathrm{m}^{3} /$ day of T-N loading. The optimal operating condition, i.e. $30 \mathrm{~min}$. aeration on and $30 \mathrm{~min}$. aeration off, was obtained in this study.

(3) Fluctuation patterns of DO and ORP in one cycle were effective indices for regulation of operation. ORP was desirable to change from not less than $-100 \mathrm{mV}$ to more than $+100 \mathrm{mV}$ in one cycle in intermittent aeration mode for nitrogen removal.

(4) Introducing anoxic operating condition to the system, the specific INT-dehydrogenase activity of sludge decreased. However, the volumetric activity did not decrease significantly.

(5) Based on SEM observations, there were no significant differences of sludge structure with those in continuous aeration mode. The type of bacteria did not change significantly when anoxic operating condition was introduced to the system. The rod-type bacteria were predominant compared with filamentous bacteria at higher MLSS concentration.

ACKNOWLEDGMENTS: The authors wish to express the gratitude to Hitachi Plant Engineering \& Construction Co., Ltd. for providing rotary disk type UF membrane, Ms. Toshimi Yamamoto of Yamaguchi University and Mr. Toshio Harada of Ube National College of Technology for their kind help and advice in chemical analysis.

\section{REFERENCES}

1) Magara, Y., Nishimura, K., Itoh, M. and Tanaka, M. : Biological denitrification system with membrane separation for collective human excreta treatment plant, Water science and technology, Vol.25, No.10, pp.241-251, 1992.

2) Smith, C. V., Gregorio, D. D. and Talcott, R. M.: The use of ultrafiltration membranes for activated sludge separation, Ind.
Waste Conf. Purdue Univ. 24, pp.1300-1310, 1969.

3) Ohkuma, N., Shinoda, T., Aoi, T., Okaniwa, Y. and Magara, Y.: Performance of rotary disk modules in a collected human excreta treatment plant, Water science and technology, Vol.30. No.4, pp.141-149, 1994.

4) Delanghe, B., Nakamura, F., Myoga, H. and Magara, Y. : Biological denitrification with ethanol in a membrane bioreactor, Environmental Technology, Vol.15, pp. 61-70, 1994.

5) Muller, E. B., Stouthamer, A. H., van Verseveld, H. W. and Eikelboom, D. H. : Aerobic domestic waste water treatment in a pilot plant with complete sludge retention by cross-flow filtration, Water Research, Vol.29, No.4, pp.1179-1189, 1995.

6) Bailey, A. D., Hansford, G. S. and Dold, P. L. : The use of crossflow microfiltration to enhance the performance of an activated sludge reactor, Water Research, Vol.28, No.2, pp.297-301, 1994.

7) Chiemchaisri, C., Wong, Y. K., Urase, T. and Yamamoto, K.: Organic stabilization and nitrogen removal in membrane separation bioreactor for domestic wastewater treatment. Water science and technology, Vol.25, No.10, pp.231-240. 1992.

8) Lu, S. G., Imai, T., Ukita, M., Sekine, M., Fukagawa, M. and Nakanishi, H. : Characterization of highly concentrated activated sludge in fermentation wastewater treatment coupled with rotary disk type UF membrane, J. Environ. Syst. and Eng., JSCE, 1999. (in press)

9) Chiemchaisri, C. and Yamamoto, K.: Biological nitrogen removal under low temperature in a membrane separation bioreactor, Water science and technology, Vol.28. No.10. pp.325-333, 1993.

10) Somiya, I., Tsuno, H. and Yamashita, H. : Nitrogen removal in membrane separation activated sludge process with intermittent aeration, J. Japan Sewage Works Association, Vol.33, No.407, pp.104-118, 1996 (in Japanese).

11) Ohba, S. and Sakai, Y. : Sewage treatment characteristics by single-stage intermittent aeration system, J. Japan Sewage Works Association, Vol.31, No.379, pp.16-33, 1994 ( in Japanese).

12) Ohba, S. and Sakai, Y. : The proposal of design method for the single-stage intermittent aeration system, J. Japan Sewage Works Association, Vol.31, No.379, pp.34-48, 1994 ( in Japanese).

13) APHA, AWWA and WPCF : Standard Methods for the Examination of Water, 18th edition, American Public Health Association, Washington D.C., 1992.

14) Logue, C., Koopman, B., ASCE M. and Bitton, G. : INTreduction assays and control of sludge bulking, J. Envir: Engng., Vol.109, pp.915-923, 1983.

15) Suwa, Y., Suzuki, T., Toyohara, H., Yamagishi, T. and Urushigawa, Y.: Single-stage, single-sludge nitrogen removal by an activated sludge process with cross-flow filtration, Water Research, Vol.26, No.9, pp.1149-1157, 1992.

16) Wild, H. E., Sawyer, C. N. and McMahon, T. C. : Factors affecting nitrification kinetics, J. Water Poll. Contro. Fed., Vol.43, No.9, pp.1845-1854, 1971

17) Shammas, N. Kh. : Interactions of temperature, $\mathrm{pH}$, and biomass on the nitrification process, J. Water Poll. Contro. Fed., Vol.58, No.1, pp.52-59, 1986.

18) Yuyama, Y., Fujino, K., Miyamoto, Y. and Oonishi, R. 
Treatment system of wastewater from rural settlements with batch-activated sludge process, Water science and technology, Vol.28, No.10, pp.223-232, 1993.

19) Koch, F. A. and Oldham,W. K.: Oxidation-reduction potential - a tool for monitoring, control and optimization of biological nutrient removal systems, Water science and technology, Vol.17, Paris, pp.259-281, 1985.

20) Kim, C. W., Koopman, B. and Bitton, G.: Int-dehydrogenase activity test for assessing chlorine and hydrogen peroxide inhibition of filamentous pure cultures and activated sludge, Water Research, Vol.28, No.5, pp.1117-1121, 1994.

21) Imai, T., Ukita, M., Sekine, M., Nakanishi, H. and Fukagawa. M. : A study on treatment of high strength fermentation wastewater consisting of high sulfate and ammonia by UAHB process, J. Environ. Syst. and Eng., JSCE, No.573, pp49-59, 1997 (in Japanese).

(Received July 13, 1998)

\title{
回転平膜を用いた高濃度活性污泥法による発酵廃液処理 における有機物及び窒素除去に関する研究
}

\author{
呂 樹光·今井 剛 ·浮田正夫 ·関根雅彦・深川勝之 · 中西 弘
}

回転平膜を用いた高漕度活性污泥法による発醭廃液の処理において,様々な間欠曝気条件を設定して実験 を行い, 有機物及び窒素除去に関して検討した. 有機物除去に関して, 連続曝気を行った場合と比較して間 欠曝気による影響はほとんど認められなかった，T-Nの除去量は，脱窒によるものがほとんどであり，サン プリング及び菌体合成によるものは少なかった。 DO及びORPの変動パターンを測定し，これらが運転指標 として有効であること,さらに, INT脱水素醭素活性による菌体活性を測定し，間欠曝気による活性低下が ほとんどないことを確認した．SEMによる菌体観察の結果, 高 MLSS 域において桿菌が糸状菌に比較して 優占種となっていた．本プロセスに扔ける最適間欠曝気条件は，30 分曝気-30 分無曝気と推定された。 